\title{
The Hungarian Dilemma from a Pluralist Perspective
}

VB verfassungsblog.de/the-hungarian-dilemma-from-a-pluralist-perspective/

Matej Avbelj Mi 8 Mai 2013

Mi 8 Mai

2013

The constitutional and political developments in Hungary in the last few years have stirred a lot of controversies and also raised significant academic attention. This blog has provided not only a wonderful forum for an exchange of different views, but it has also produced original and thought-provoking proposals for tackling the Hungarian problem.

However, the "reverse Solange" idea, the call for the establishment of a special Copenhagen Commission, for a straightforward supremacy of the Charter and other insightful proposals, all appear to be addressing the Hungarian dilemma from within the constitutional register. This is, of course, a legitimate choice, but it is neither exclusive nor neutral.

As the Lindseth-Halberstam exchange in particular demonstrated, the answers sketched for the resolution of the Hungarian dilemma are heavily dependent on the assumed or the desired character of the European Union. Without engaging with the merits of the constitutional account of the European Union and without necessarily taking sides, I would like to use this post to explore - out of intellectual curiosity - the Hungarian dilemma from a pluralist perspective.

The European Union as a pluralist entity is a union (der Bund). It is composed of autonomous national and supranational constitutional sites, which form a non-hierachical common whole, founded on a relational principle of primacy, rather than supremacy. In a pluralist Union boundaries, jurisdictions and competences matter. They do so not merely because of the formal reasons (eg since the Treaty stipulates so), but because they are a guarantee and a sign of respect for autonomous development: for a veritable self-government of the Union's constituent entities.

Therefore not every constitutional conflict inside a Member State is automatically turned into a supranational EU affair. A national constitutional conflict can trigger an EU reaction, if it causes negative externalities: be it to the other Member States, to the EU or to the EU citizens. It should also lead to the EU reaction when a Member State violates the normative spirit of pluralism, by undermining the double commitment: to the plurality and to the common whole, both at the same time.

The EU's intervention should be therefore exceptional, rather than a rule, and it should be exercised with selfrestraint too. This is so for three reasons: the legal-jurisdictional; the reasons related to substantive democratic legitimacy; and the reasons related to the Union's pluralist character.

First, the Union is based on the principle of conferral of powers. The EU can only act when it is authorized to do so. It can therefore start an (legal) action against a Member State only in explicitly enumerated cases.

Second, the EU has traditionally suffered from a democratic deficit. This indicates that it lacks not only strong legal grounds for the intervention against the Member States, but also substantive legitimacy to do so. In contrast with the classical federal states, such as the USA or Germany, the locus of democratic legitimacy in the EU still rests on the national rather than on the supranational level. Therefore, if in a classical federal system a state level is looked upon with suspicion, it might be still the other way around in the EU.

Third, the Union is a legally pluralist entity because of the value pluralism that it embodies. Legal orders as forms shield different understandings of the substance of the values in the constituent entities of the Union. Following the pluralist understanding, there is no value unity or uniformity in the Union. A great majority of the fundamental constitutional values is shared, but they are not identical or homogeneous across the Union. Even if nominally the same, they are - due to each entity's distinctive episteme - understood and practiced differently.

In other words, pluralism allows to each entity of a pluralist construction to strike its own balance of fundamental 
values. Simultaneously, each entity is entitled to its own irreducible epistemic core, to its own constitutional identity, which is unamendable or non-derogable lest the entity's autonomous character is lost. Moreover, in a pluralist constellation there is also no ultimate authority to decide for all the entities involved on a single correct balance of fundamental values or on the ultimate suitability of a given constitutional settlement.

The implications of this are the following. In case of a Member State purely internal constitutional conflict the EU should first approach it with a degree of trust that a national polity is able to resolve it by itself. This is after all its right if the autonomy of a polity shall preserve any meaning. Only when the conflict creates externalities or when it affects the alleged fundamentals of a constitutional order, the EU can and sometimes indeed should act.

In doing so, its measures should be guided by the principles of subsidiarity and proportionality. They should match the gravity of the alleged national violation. The measures should be used incrementally: ranging from the least to the most stringent ones. If these were depicted as on a continuum, they should consist of soft diplomatic measures, political pressures, initiation of legal proceedings, actual filing of applications before the CJEU, economic sanctions, suspension of voting rights.

Indeed, the pluralist vision allows for an integral approach to sanctioning a Member State, but this must be done in accordance with the law and, more broadly, in accordance with the pluralist character of the Union. Any EU intervention must be taken with a reminder that the EU too lacks legal powers; that it lacks legitimacy; that there should be no uniform constitutional model across the Union and that even the most fundamental constitutional values might be legitimately understood and practiced differently in different Member States.

A pluralist vision therefore rejects the extension of the EU competences beyond the enumerated powers. Indeed, as argued by Daniel Thym, there should be no more room for the integration by stealth, as it was practiced in the 1960s and 1970s. As the union is a pluralist entity, the Member States have to be taken seriously. The textual constraints to which they have subjected the EU institutions should be heeded. The Court should be aware of its institutional limits. The Commission should act in accordance with the law. Any action taken by the European Parliament should be conducted with the political divisiveness of the situation in mind. But once again, in purely internal situations it should be first for the national political and overall constitutional process to find the right answers.

However, having said that, the pluralist nature of the Union should not used by the recalcitrant Member State as an excuse for its measures, corrosive of the fundamental constitutional values. Pluralism leaves no room for complacency, for self-sufficiency, for self-closure, but it requires the ethics of a dialectic open-self. Irrespective of the cause of a constitutional conflict inside a Member State, its government or a ruling coalition has to be able to justify it in a dialogue with the domestic opposition as well with its counterparts in the Union. In this process of justification, the Member State (actually its governing coalition) must genuinely consider the counter-arguments and be open to reconsider its own position and to amend it.

In other words, any Member State, which in defence of its own constitutional autonomy (even identity), invokes the pluralist structure of the Union, it can only do so after it has heeded pluralism inside its own constitutional polity. In that way, pluralism can endogenously create the environment constructive of a sound national constitutional development. This is different from the constitutionalist account that in a statist-federalist manner imposes (or creates an impression of imposition) of "foreign" constitutional values top-down.

However, as the historical experience of failed unions teaches us, pluralism is a demanding normative order, since it always (in most abstract terms) oscillates between the openness to the other and the complacent selfclosure. If a country, such as Hungary, indeed decides for a slide into authoritarianism, as alleged and feared by many, this will reveal that it has given up on a normative spirit of pluralism.

In such a case, there are not many alternatives left. Pluralism may be reclaimed through the national political process. It can be, indeed, imposed top down by the EU. Yet, this is a monist, constitutional solution which teaches a Member State a lesson in "the right" pluralism, while the latter has given up its own autonomous pluralist self. And finally, such a country can leave a pluralist entity and continue in all respects a monistic and therefore ever more authoritarian journey. 
Obviously, the first alternative is the best solution. Pluralism is either endogenous or it makes no sense. If the European Union is to remain a pluralist entity - the EU, the Member States, and in particular Hungary, should be aware of the fragility of its construction and act accordingly. If they do not, the system will be either constitutionalized top-down or subject to disintegration. In either way something of great importance to the European project will be lost.

\section{LICENSED UNDER CC BY NC ND}

SUGGESTED CITATION Avbelj, Matej: The Hungarian Dilemma from a Pluralist Perspective, VerfBlog, 2013/5/08, http://verfassungsblog.de/the-hungarian-dilemma-from-a-pluralist-perspective/. 